\title{
The influence of Hypholoma fasciculare and Phlebiopsis gigantea on the growth of Heterobasidion annosum in vitro
}

\author{
PIOTR ŁAKOMY, JOANNA ZIENIEWICZ, and TOMASZ SWIDKIEWICZ \\ Department of Forest Pathology, August Cieszkowski Academy of Agriculture \\ Wojska Polskiego 71c, PL-60-625 Poznań, Poland
}

Eakomy P., Zieniewicz J., S widkiewicz T.: The infitience of Hypholoma fasciculare and Phiebiopsis gigantea on the growth of Heterabasidion annosum in vitro. Acta Mycol. 33 (1) $147-154,1998$

The influence of two saperotrophes - isolates of Hypholoma fasciculare and Phlebiapsis gigantea on the growth of thirty thres root pathogen strains - Heterobesidion annosum was analysed. Two methods were used. The different reaction in paired cultures among saprotrophe and pathogen isolates suggest, that one isolate of $H$. ammosum is not enough to study the interaction between this pathogen and saprophytes in vitro irrespective of the method used.

Key werds: Heterobasidion annosum, Hypholoma fasciculare, Phlebiopsis gigantea.

\section{INTRODUCTION}

Heterobasidion annosum (Fr.) Bref. causes one of the most dangerous diseases in forests all over the world ( $\mathrm{G} \mathrm{r} \mathrm{e} \mathrm{m} \mathrm{m} \mathrm{e} \mathrm{n} \mathrm{1970;} \mathrm{H} \mathrm{u}$ b b e s 1980; M a n k a 1992). This fungus due to butt and root rot of coniferous and sometimes deciduous trees. Control of this pathogen is difficult since it can spread by root-to-root contact or by spores which infect stumps left in the soil after thinning in stands or clear-cutting in the next generation ( $\mathrm{M}$ a $\mathrm{n} \mathrm{k}$ a 1986, 1991). Heterobasidion annosum can also survive as saprophyte in woody substrates for decades (S c h ü t t et al. 1979).

The biological control is associated with of replacing the pathogen or preventing stumps by other organisms. Such as Phlebiopsis gigantea ( $\mathrm{Fr}_{\text {.: }} \mathrm{Fr}_{\text {r }}$ ) Jülich and Trichoderma spp., or Hypholoma fasciculare (Huds: Fr.) Kummer (Twarowska 1972; Lundberg and Unestram 1981; Rhisbeth 1979; Sierota and Sternak 1993; Sierota 1995). 
The objectives of this study were to determine: a - whether the growth of all using pathogen isolates is suppressed by different saprotrophe strains; b - whether the diversity of growth in paired cultures inside the pathogen population is higher than in saprotrophes.

\section{MATERIALS AND METHODS}

The pathogen. Heterobasidion annosum was represented by thirty three strains from $\mathrm{P}$ intersterility group, obtained by isolation from roots of dead Scots pines localised in two plantations (Podanin Forest District) in 1995. Each isolate belonged to different clones, which were identified on the basis of demarcation line formation (somatic incompatibility) between paired heterokaryotic cultures (S t e n lid 1985; P i r i 1996).

The saprotrophes. Four strains of Hypholoma fasciculare were isolated from basidiomes, which were collected from oak stumps (Podanin, Babki and Zielonka Forest Districts) in 1996. The fifth strain was obtained from "HF" - biopreparation.

Three strains of Phlebiopsis gigantea were derived from Italy (Austrian pine), Finland (Scots pine) and Poland ("PG" - biopreparation).

Influence in vitro. The influence of Hypholoma fasciculare and Phlebiopsis gigantea on Heterobasidion annosum growth in vitro was estimated by two methods - the biotic series described by $\mathrm{M}$ a n k a (1974) and the method described by M a r x (1969). All the isolates of Hypholoma fasciculare and Phlebiopsis gigantea were tested for their individual biotic effect on growth of 33 Heterobasidion annosum strains. Isolates were inoculated on $1.5 \%$ malt agar and the test was estimated after 10 days of incubation at room temperature according to the scale described by M a ń k a (1974).

In the second method the radial growth of mycelium was recorded (in millimetres) after 10 days of incubation at room temperature on $1.5 \%$ malt agar.

The data were subjected to analysis of variance.

\section{RESULTS}

The results of the biotic tests are presented in Table 1. The individual biotic effect for isolates of Hypholoma fasciculare varied from -5 (H. fasciculare $96016+H$. annosum 95109$)$ to $+6(H$. fasciculare $96018+H$. annosum 95125). The biggest range of IBE on different strains of $H$. annosum was observed for $H$. fasciculare 96018 (from -4 to +6 ) and the smallest range of IBE for $H$. fasciculare 96020 (from -2 to +2 ). The growth of each isolate 


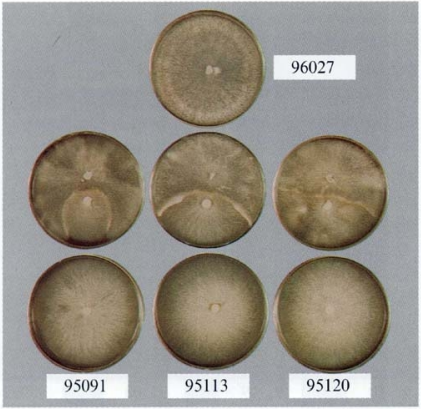

Fig. 1. Phlebiopsis gigantea 96027 (top) and Heterobasidion annosum (bottom): from left $95091,95113,95120$ isolates in paired cultures (middle) in biotic series method 


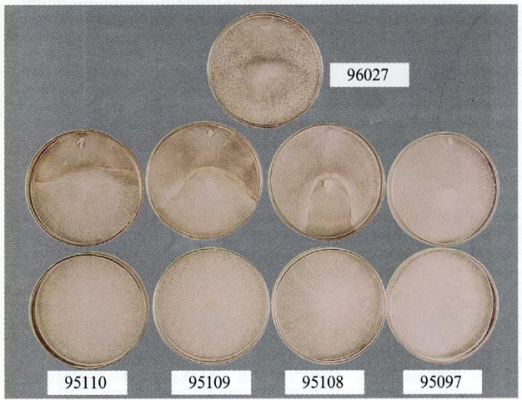

Fig. 2. Phlebiopsis gigantea 96027 (top) and Heterobasidion annosum (bottom): 95110 , $95109,95108,95097$ isolates in paired cultures (middle) in Marx's method 
T a b le 1

Some examples of individual biotic effect of Hypholoma fascicmiare and Phlebiopsis gigantea isolates influence on the growth of Heterobasidion arnosum

\begin{tabular}{|c|c|c|c|c|c|c|c|c|c|c|c|}
\hline \multirow{2}{*}{ Isolate No } & \multicolumn{11}{|c|}{ Hererobasidion annosum } \\
\hline & 95090 & 95093 & 95095 & 95099 & 95104 & 95107 & 95117 & 95120 & 95122 & 95125 & 95133 \\
\hline $\begin{array}{l}\text { H. fasciculare } \\
96016\end{array}$ & $+2^{* 2=1}$ & $+3^{n s}$ & $-1^{* *}$ & $+1^{m s}$ & $-4^{* *}$ & $-2^{4}$ & $+2 * *$ & $-2^{* *}$ & $\alpha^{m}$ & $+2 *$ & $-4^{m i}$ \\
\hline 96018 & -2 & +4 & -2 & -1 & -1 & 0 & +1 & +3 & +1 & +6 & +1 \\
\hline 96019 & +2 & +2 & -1 & -1 & -1 & -2 & +1 & 0 & 0 & +5 & -1 \\
\hline 96020 & +1 & +2 & 0 & -2 & -2 & -2 & 0 & 0 & -1 & +2 & -1 \\
\hline 96024 & -1 & +3 & 0 & +1 & -2 & 0 & +1 & +3 & 0 & +2 & -1 \\
\hline $\begin{array}{l}\text { Ph. giganiea } \\
96027\end{array}$ & $+6^{\mathrm{ns}}$ & $+6^{n s}$ & $+2^{n s}$ & $+3^{* *}$ & $+3=$ & $+3^{\mathrm{ns}}$ & $+2^{\mathrm{mm}}$ & $+2^{*}$ & $+8^{\mathrm{ms}}$ & $+5^{n s}$ & $+5+4$ \\
\hline 96028 & +8 & +7 & +3 & +7 & +4 & +5 & +5 & +3 & +8 & +7 & +4 \\
\hline 96029 & +7 & +6 & +5 & +5 & +4 & +5 & +4 & +3 & +6 & +5 & +3 \\
\hline
\end{tabular}

*1 - significant differences in IBE of influence of all saprotrophes isolates on the growth of one $H$, wrmasta isolate

*2 - significant differences in IBE of inlluence of one saprotrophe isolate oa the growth of all $H$. anmestan isolates

* $-\mathrm{a}=0.01$

of $H$. fasciculare was suppressed by some isolates of $H$. annosum. Moreover the growth of other pathogen isolates was restricted by the same saprotrophe isolate. Only three isolates of $H$. annosum were suppressed by all $H$. fasciculare isolates and two isolates of $H$. fasciculare were suppressed by all the isolates of the pathogen. The isolate from the biopreparation was suppressed by the highest number of $H$. annosum isolates (20). The analysis of variance displayed significant differences in IBE estimation for each $H$. fasciculare isolate influence on the growth of all the $H$. annosum isolates. In 12 cases the influence of all $H$. fasciculare isolates on the growth of one $H$. annosum isolate did not differ significantly.

Isolates of Phlebiopsis gigantea suppressed the growth of the all Heterobasidion annosum isolates. The IBE for $P$ h. gigantea varied from $+2(P h$. gigantea $96027+H$. annosum 95095 ; Fig. 1) to +8 (e.g. Ph. gigantea $96028+$ $H$. annosum 95090). The biggest range of IBE on different isolates of H. annosum was estimated for $P h$. gigantea 96027 (from +2 to +8 ) and the smallest one for Ph. gigantea 96029 (from +3 to +8 ). The analysis of variance showed significant differences in IBE estimation for each $P$ h. gigantea isolate influence on the growth of all the H. annosum isolates. In 22 cases the differences in the influence of all $P h$. gigantea isolates on the growth of one H. annosum isolate were not statistically significant. 
P. Lukomy, J. Zieniewicz, T. Swidkiewicz

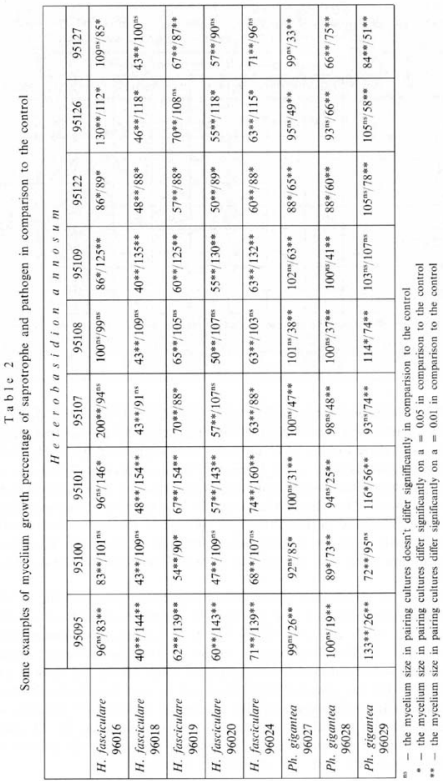


The results of the method described by $\mathrm{M}$ a $\mathrm{r} x$ are presented in Table 2 . In most cases $H$. fasciculare isolates restricted the growth of $H$. annosum cultures. The pathogen growth was inhibited by $1-53 \%$ (Fig. 2). The isolate of H. fasciculare used in the biopreparation restricted the growth of the greatest number of $H$. annosum isolates. The growth stimulation was also estimated for H. annosum $(1-60 \%)$ cultures. In paired cultures a reduced growth reduction of $H$. fasciculare isolates was observed. Only in three cases the cultures of $H$. fasciculare isolate from the biopreparation was bigger in comparison to the control $(9 \%, 30 \%$ and $100 \%)$. The analysis of variance showed significant differences between the growth of $H$. fasciculare and $H$. annosum isolates in paired cultures. Only Hypholoma fasciculare cultures from the biopreparation did not differ significantly from the control in about $50 \%$ of the cases.

Each isolate of Phlebiopsis gigantea inhibited the growth of all the H. annosum isolates by $3 \%-81 \%$. In one case only the pathogen culture was bigger than the control $(7 \%)$. The pathogen isolates also restricted the growth of $P h$. gigantea by $1 \%-36 \%$. In most cases $(20)$ the cultures of $P h$. gigantea (96027) from the biopreparation were bigger than the control. The analysis of variance showed significant differences between.

\section{DISCUSSION}

In both experiments the saprotrophs influence on the growth of Heterobasidion annosum isolates was different. The results of IBE and the diameter of cultures were significantly different for each pathogen isolate. Moreover the same type of relation was observed for saprotrophe isolates. All the authors used only one isolate of Heterobasidion annosum in biotic series ( P r z e zbór s k i 1974; M a n k a et al. 1991; S i e r o t a 1995). It was demonstrated that the isolates derived from different stocks reacted differently in paired cultures in both methods. In addition some of these $H$. annosum cultures were isolated from roots of killed trees localised in one mortality gap. $\mathrm{M}$ a ń k a et al. (1993) showed that only one isolate of species from fungal community may be use as a representative. However the isolates of the same species from different fungal communities would exert a different individual biotic effect on the same pathogen growth ( $\mathrm{M}$ a n $\mathrm{k}$ a et al. 1993; Kow a lsk i 1989; K urzawińs ka 1992, 1993). Werner et al. (1995) indicated that various $H$. annosum stocks could be inhibited in a different way by soil saprotrophes. It seems that one isolate of $H$. annostum is not enough to estimate the influence of saprotrophe on pathogen in paired cultures. The IBE for influence of $H$. fasciculare on the growth of different H. annosum stock varied from -4 to +6 and of Phlebiopsis giganiea from +2 to +8 . Sie rota (1996) tested two isolates of H. fasciculare with 
H. annosum. He found that the IBE for the isolate derived from stump roots of the 1st generation pine of post-agricultural land was +3 and for the isolate derived from the roots of the 2 nd generation: +4 . P r ze z b o r s k i (1974) also used in the biotic series two isolates of $\mathrm{H}$. fasciculare that were isolated from Scots pine stumps localised in two different stands. The IBE in this case was the same -3 . The results of Marx tests were also significantly different. The growth of $H$. fasciculare isolate from biopreparation was inhibited by 20 pathogen isolates in biotic series. At the other hand this saprotrophe isolate restricted the growth of 12 isolates of $\mathrm{H}$. annosum but in the same time its growth was suppressed by 14 pathogen isolates in Marx test. This test makes it possible to determine the influence of saprotrophe on the pathogen growth and also the opposite situation in paired cultures. Not only the restriction but also the stimulation of mycelium growth could be estimated by means of the Marx test. M a t k ow s k i (1996) used seven isolates of the Pyrenochaeta terrestris (Hansen) Gorenz, Walker et Larson and one Fusarium oxysporum isolate in biotic series. The IBE varied from +3 to -3 .

Genetically different isolates of Heterobasidion annosum show higher variability of growth than saprophytes in paired cultures. Irregular damages caused by this pathogen and different disease spreading in Scots pine stands suggest that the variability concerns also the virulence of isolates belonging to different clones.

\section{Acknowledgements}

The authors would like to thank Mr Jerzy Dux for sending his Hypholoma fasciculare and Pltebiopsis girantea isolates and Dr Kari Korhonen for Phlebiopsis giguntea isolates.

\section{REFERENCES}

G r e $\mathrm{m} m$ en J. 1970. The actual situation of research and control of the root rot fungus (Fomes annosus) in the Netherlands. Proc. 3rd Int. Conf on Fomes annosus, IUFRO, Denmark, 1968: $33-36$.

$\mathrm{Hu}$ b bes M. 1980. Fones ameisus in Canada. In: L. Dimitri (ed.). Proc of 3 th conference on root and butt rots. Kassel: Intern. Union Forestry Res. Organisa: 40-42.

K o w a Iski S. 1989. Study on the effect of mycorrhizosphere fungi on growth of Helere. bessidion annesum in plantation in a zone of strong pollution with industrial emissions. proc. of the 7th Int. Conf, on Root and Butt Rots, 9-16 August 1988. British Columbia, Canada. Ed. D.J. Morrison. for. Can. Pacif For. Cent. Can. V8Z IM5: 477-485.

$\mathrm{K}$ u r z a w i i s $\mathrm{k}$ a H. 1992. The effect of fungal communities in soil environment of potato crop on the growth of pathogens Fusarium sulphuretum Schl. and Fisarian coeruleum (Sacc) Booth. Phytopathol. Polon. 16: $5-16$.

$\mathrm{K}$ ur z a win $5 \mathrm{k}$ a H. 1993. The effect of fungi isolated from soil environment on agents of dry rot of potato - Fusarium stphureum Schl. and Fusarian coeruleam (Sace.) Booth. Phytopathol. Polon, 18: 13-18. 
$\mathrm{L}$ u n d be fg A, U n est $\mathrm{ram}$ T. 1981. Antagonism against Fomes amosus. Comparison between different test methods in vitro. Mycologia. 70: 107-115.

$\mathrm{M}$ a n k a K. 1974. Zbiorowiska grzybów jako kryterium oceny wplywu srodowiska na choroby rosilin [Fungal communites as a cryterion for estimating the effect of the environment on plant diseases] 7esz. Probl. Post. Nauk Rol. 160:9-23.

$\mathrm{M}$ a n k a K. 1986. Trzebieże jako zabiegi przeciwdrialające występowaniu huby korzeni (Helerobasidion annosum ( $\mathrm{Fr}$.) Bref) i zamjeraniu pęów sosny (Gremmeniella abietina (Lagerb.) Morclet) [Thinnings as a treatment couneracting the occurrence of Heferohasidion annosum (Fr.) Bref. and Grenmeniella abietina (Lagerb) Morelet]. Sylwan 7: 1-8.

M a n k a K. 1991. Huba korzeni. Folder nr 6 z serii Choroby Drzew Leśnych. PWRiL, Poznan. $\mathrm{M}$ a n k a K. 1992. Fitopatologia lesna. PWRiL. Warszawa.

Manka K., K waśna H., Babkicwicz M. Kazimicrezak. T. 1991. Biotic resistance of soil to plant pathogens. Proceedings of the first conference of the European Foundation for Plant Pathology "Biotic interactions and soil-borne diseases". Netherlands Soc. Plant Pathol, Elsevier, Amsterdam-Oxford-New York-Tokyo: 311-315.

$\mathrm{Mank}$ a M., D y m e k A., Pie c h ow s k K. 1993. Biotic series method for evaluation of soil fungi effect on plant pathogenic fungi. 1. Raplicability of individual biotic effect measurement in the biotic series method. Phytopathol, Polon. 18: 87-98.

M a r $x$ D. H. 1969. The influence of ectotrophic mycorrhizal fungi on the resistance of pine roots to pathogenic infections. Phytopathol. 59: 153-163.

Ma tkowski. K. 1996 . Wstẹpne badania nad wzajemną reakcja pomiędzy Pyrenochaeta terrestris (Hansen) Gorenz, Walker et Larson i Fusarim oxysporum Schlecht. Choroby Roslin a Srodowisko. Matcrialy z sympczium naukowego, Poznań, 27-28.06.1996: 329-336.

P it i T. 1996. The spreading of the S type of Heterobasidion annosum from Norway spruce stumps to the subsequent tree stand. Eur. J. For. Path. 26: 193-204.

Przez bórski A. 1974. Zagadnienie huby korzeni na tle mikologicznej analizy pniaków sosnowych. Zesz. Probl. Post. Nauk. Roln. 160: 47-86.

$\mathrm{R}$ is h be i h. J. 1979. Modern aspects of biological control of Fomes and Armillaria. Eur. J. For. Path 9: $331-340$.

Sierota Z 1995, Rola grzyba Phlebiopsis giganiea (Fr: Fr.) Jülich w ograniçaniu huby korzeni w drzewostanach sosny zwyczajnej (Pims sylvestris L.) na gruntach porolnych. Prace IBL. 810, seria A

S i e r o t a Z 1996. Biotic activity of fungal communities against a pathogen - a proposal of evaluation with the use of "biotic effect coefficients". Phytopathol. Polon. 12: 5-13.

S i e r o t a Z, S t e r n a k A., 1993. Zagrożnia II generacji sosny ze strony huby korzeni na gruntach porolnych. Las Polski 19: 10-11.

S te $\mathrm{n}$ lid J. 1985. Population structure of Heterobasidion annosian as determined by somatic incompatibility, sexual incompatibility, and isoenzyme patterns. Can. J. Bot. 63: 2268-2273.

Schüt P., Schuck H. J., Lautenschlagef. K., Prestleu W, St im m B. 1979. Fomes amnosus sporocarps - their abundance on decayed logs left in the forest. Eur. J. For. Path. 9: 57-61.

Twa rowska I. 1972. Badania nad zwalczaniem huby korzeniowej metodą biologiczną [Investigation on the biological control of the root rot]. Prace IBL 405: 1-55.

Werner. M. Werner A., A ndrzej a k R. 1995. Antagonistic effect of some soil fungi on Fusaritan oxysporum and Heterabasidion annosum in laboratory cxperiments. Environmental Biotic Factors In Integrated Plant Discasc Control. European Foundation for Plant Pathology; 3rd Conference Polish Phytopatol Soc., 5-9. 09. 1994: 611-616. 


\section{Wplyw Hypholoma fasciculare i Phlebiopsis gigantea \\ na wzrost Heterobasidion annosum in vitro}

\section{Streszczenie}

Testowano wplyw pięciu izolatów Hyphoiona fasciculare i trzech Phlebiopsis gigantea na wzrost 33 izolatów patogena Heterobasidion annosum typu $\mathrm{P}$ in vitro. W tym celu poshizono się dwicma metodami: metoda szeregów biotycznych opisana przez Mankę (1974) oraz metodą opisaną przez Marxa (1969). Indywidualny efekt biotyezny okreslony dla kultur dwugrzybowych H. fasciculare $+H$. amosum byl rózny i wynosil od -5 do +6 . Tylko trzy izolaty patogena byly ograniczane przez wszystkie izolaty $\boldsymbol{H}$. jasciculare, natomiast wzrost dwóch izolatow saprotrofa. był ograniczany przez wszystkie izolaty $H$. annosim. Indywidualny efekt biotyczny w testach $P h$. gigantea wynosit od +2 do +8 . Jednoczynnikowa analiza wariancji wykazala statystycznie istotne różnice w ocenach wplywu każdego izolatu $\boldsymbol{H}$. fasciculare i $P h$. gigantéa na wszystkie izolaty $\boldsymbol{H}$ - amosum. Na podstawie testu Marxa stwierdzono, że w większości przypadków izolaty H. fasciculare ograniczaly wzrost patogena $(1-53 \%)$. Obserwowano także stymulację wzrostu $H$. annosum $(1-60 \%)$ oraz jednocześnie ograniczenie wrrostu izoaltów $H$. fasciculare. $\mathrm{Z}$ kolei każdy izolat $P h$. gigantea ograniczal wzrost wszystkich izolatów patogena $(3-81 \%)$, ale nicktóre izolaty saprotrofa byly równocześnie ograniczane przez $H$. armosum $(1-36 \%)$. W wiclu przypadkach jednoczynnikowa analiza wariancji wykazała ststystyeznie istotne różnice pomiędzy wielkoś. ciami grzybni testowanych izolatów w kulturze dwugrzybowej w porównianiu $z$ grzybniami kontrolnymi. 